\title{
MODAL SOSIAL MASYARAKAT BONOKELING DALAM PELESTARIAN LUMBUNG PACEKLIK DI DESA PEKUNCEN KECAMATAN JATILAWANG KABUPATEN BANYUMAS
}

\author{
Reni Irkhatin \\ Politeknik Kesejahteraan Sosial Bandung, Jalan Ir. H. Djuanda 367 Bandung, reni.irkhatin4@ gmail.com \\ Milly Mildawati \\ Politeknik Kesejahteraan Sosial Bandung, Jalan Ir. H. Djuanda 367 Bandung, millystks@gmail.com \\ Ade Subarkah \\ Politeknik Kesejahteraan Sosial Bandung, Jalan Ir. H. Djuanda 367 Bandung, ade_subarkah@yahoo.com
}

\begin{abstract}
Social capital the parts of social organization such as faith, norms, and networks. This research to describe Bonokeling community's social capital in preserving public granaries in Pekuncen. The objectives of this research are to retrieve data, and to description about: 1) The characteristics of informants 2) Trust built 3) Network pattern among Bonokeling community, and outside the community 4) Norms exist. Descriptive is the method applied in this research. By applying qualitative approach, this research is purposed to describe. There are six informants involved in this research, who were chosen by purposive sampling method. The data of the research are used indepth interview, non-participant observation, and documentation study. The results of this research are social capital in preserving public granaries is quite good. This statement is proven of trust and participation from Bonokeling community young members. This trust crisis is precipitated by the unavailability of bonds between community members, and the lack of understanding from the elder members to the young members. The network pattern is pretty good. Bonokeling community members create networks among themselves and those outside the community, who in this case are the rice merchants. The existing norms in applying public granaries are good. It is proven by the existence of unwritten laws and sanctions. Based on the research result, the researcher proposes a program entitled "Social Capital Optimization through Public Granaries' Management." This program is proposed to optimize the quality of social capital in preserving public granaries that exists in this community, especially, the young generations.
\end{abstract}

Keywords:

Social Capital; Bonokeling Community; Public Granaries

\begin{abstract}
Abstrak
Modal sosial menunjuk pada bagian-bagian dari organisasi sosial seperti kepercayaan, norma dan jaringan. Penelitian ini dilakukan untuk memperoleh gambaran tentang modal sosial masyarakat Bonokeling dalam pelestarian lumbung paceklik di Desa Pekuncen Kecamatan Jatilawang Kabupaten Banyumas. Tujuan penelitian ini untuk memperoleh data dan gambaran yang jelas mengenai: 1) Karakteristik informan, 2) Rasa saling percaya yang dibangun masyarakat Bonokeling, 3) Pola jaringan yang terjalin pada sesama masyarakat Bonokeling dan pihak luar, 4) Norma yang berlaku pada masyarakat Bonokeling. Metode yang digunakan dalam penelitian ini adalah metode deskriptif dengan pendekatan kualitatif. Jumlah informan dalam penelitian ini sebanyak 6 orang dengan teknik purposive sampling yaitu pertimbangan dan tujuan tertentu.Teknik pengumpulan data yang digunakan yaitu wawancara mendalam, observasi non partisipatif dan studi dokumentasi. Hasil penelitian menggambarkan bahwa modal sosial masyarakat Bonokeling dalam upaya melestarikan lumbung paceklik cukup baik. Hal ini dibuktikan dengan adanya rasa saling percaya yang dibangun sesama masyarakat Bonokeling mengalami kemerosotan partisipasi dari generasi muda. Pola jaringan yang terjalin cukup baik, masyarakat Bonokeling menjalin jaringan dengan sesamanya dan pihak luar yaitu penjual padi. Norma yang berlaku dalam pelestarian lumbung paceklik sudah baik ditandai dengan masyarakat yang memiliki aturan serta sanksi. Berdasarkan hasil penelitian maka peneliti mengusulkan program "Optimalisasi Modal Sosial Melalui Manajemen Pengelolaan Lumbung Paceklik". Program ini bertujuan untuk mengoptimalkan kualitas modal sosial dalam melestarikan lumbung paceklik yang ada pada masyarakat Bonokeling khususnya generasi muda.
\end{abstract}

Kata Kunci:

Modal Sosial; Masyarakat Bonokeling; Lumbung Paceklik 


\section{PENDAHULUAN}

Sejak zaman dahulu nenek moyang kita telah mewarisi berbagai nilai dan tradisi yang hingga saat ini masih dijumpai oleh masyarakat di beberapa daerah di Indonesia. Sering kali dapat dijumpai di daerah pedesaan yang masih menjunjung tinggi nilai, norma serta kepercayaan. Era globalisasi yang masuk menjadi suatu tantangan bagi masyarakat yang masih memegang erat budaya lokal dengan semangat gotong royong serta kepedulian yang masih tinggi. Globalisasi dapat memberikan perubahan positif dan negatif sehingga diperlukannya potensi termasuk kearifan lokal pada suatu masyarakat. Menurut Harry Hikmat dalam Andayani Listyawati (2017, Maret), sistem budaya lokal (local wisdom) merupakan modal sosial (social capital) yang besar, telah tumbuh dan berkembang secara turun temurun yang hingga kini berurat berakar di masyarakat. Wilayah Provinsi Jawa Tengah bagian selatan masih terdapat tradisi-tradisi Jawa yang bernuansa animistik maupun dinamistik. Salah satu wilayah yang memiliki tradisi Jawa bernuansa animistik adalah Desa Pekuncen Kecamatan Jatilawang. Masyarakat Desa Pekuncen dibagi menjadi dua yaitu penganut Bonokeling dan penganut non-Bonokeling. Menurut Bambang H. Suta Purwana (2015), Penganut Bonokeling atau yang lebih dikenal sebagai penganut Islam Aboge pada sistem budaya yang ada pada masyarakat disebut Jawa-Abangan-Sinkretis, yaitu sistem budaya yang menggambarkan pencampuran antara budaya Islam dengan budaya lokal.

Berdasarkan studi dokumentasi data kependudukan menurut Profil Desa Pekuncen Tahun 2018, jumlah penduduk Desa Pekuncen sebanyak 6.093 jiwa, terdiri dari laki-laki sebanyak 3.075 jiwa $(50,47$ persen $)$ dan perempuan sebanyak 3.018 jiwa (49,53 persen) dengan jumlah kepala keluarga sebanyak 1.800 KK. Jumlah penduduk tersebut termasuk di dalamnya anak-putu Bonokeling yang sebagaian besar tinggal di wilayah Kadus I dan III serta pusat kegiatan masyarakat Bonokeling atau disebut dengan Pasemuan adalah di wilayah RT 03 RW 01 Desa Pekuncen. Berdasarkan penuturan dari ketua kelompok masyarakat Bonokeling bahwa dari jumlah seluruh keluarga yang ada, $1.300 \mathrm{KK}$ diantaranya merupakan penganut Bonokeling (anak-putu Bonokeling).

Pada aspek sosial budaya Desa Pekuncen yang memiliki masyarakat adat Bonokeling tentunya berbeda dengan desa lain. Adapun berbagai kegiatan atau tradisi yang masih dilaksanakan biasanya disebut perlon yaitu yang setiap bulan dalam kalender Jawa sudah terjadwal mengenai kegiatan yang ada. Kondisi kehidupan sosial masyarakat Bonokeling hidup berdampingan dengan masyarakat non penganut Bonokeling secara rukun, saling bekerjasama dan saling menghormati. 
Mayoritas mata pencaharian masyarakat Bonokeling sebagai petani, yang tetap menjaga keaslian dari daerahnya sehingga memang sulit dalam menerima perubahanperubahan sosial modern. Salah satunya petani biasanya memberikan reaksi negatif terhadap segala perubahan sosial ekonomi yang datang dari pengaruh eksternal, misalnya dalam kebijakan pembangunan pertanian yang mengarah pada modernisasi sistem pertanian karena dianggap mengancam keamanan subsistensi mereka. Bagi para petani tradisional, tujuan terpenting dari semua aktivitas pertanian dan sosial adalah mempertahankan ketersediaan pangan sepanjang tahun. Masyarakat petani Bonokeling mengembangkan tradisi komunal yang mengatur masalah hubungan resiprositas ekonomi dan sosial dalam rangka untuk mempertahankan pemenuhan kebutuhan pangan khususnya saat petani menghadapi waktu kemarau berkepanjangan atau paceklik.

Demi mempetahankan kelangsungan atau jaminan ketersediaan pangan tersebut petani Bonokeling cenderung untuk terus melekat pada cara hidupnya yang tradisional. Mereka takut dengan hal-hal baru bahwa setiap perubahan-perubahan yang ada akan membahayakan keseimbangan yang rapuh di dalamnya. Kelompok petani yang ada terikat oleh hubungan emosional alamiah yang berawal dari ikatan keluarga, ketetanggaan dan pengelompokan lainnya yang bersifat lokal.
Menjaga dan mempertahankan tradisi resiprositas sosial bagi masyarakat petani Bonokeling dapat menjaga modal sosial yang mereka miliki. Sehingga melalui tradisi yang masih bertahan saat ini yang tidak dimiliki oleh desa lain adalah "Lumbung Paceklik" yang menjadi identitas masyarakat Bonokeling.

Lumbung paceklik menjadi salah satu tradisi yang penting di masyarakat Bonokeling Desa Pekuncen Kecamatan Jatilawang merupakan salah satu lingkup dalam perlindungan sosial yaitu sebagai skema mikro dan berbasis komunitas (micro and area-based schemes to protect communities). Hal ini diarahkan untuk mengatasi kerentanan pada tingkat komunitas. Konteks permasalahan yang sering terjadi pada masyarakat Bonokeling yaitu mengenai kerentanan pemenuhan kebutuhan pangan pada saat musim kemarau berkepanjangan mulai terjadi (paceklik). Masyarakat Bonokeling memiliki potensi lumbung paceklik yang ada tersebut, namun dalam pelaksanaan yang terjadi dari generasi ke generasi yang mulai tergerus era globalisasi, sehingga beberapa generasi khususnya generasi muda mulai kurang melestarikan tradisi yang ada. Oleh karena itu, pentingnya modal sosial dalam tradisi ini agar mampu mempertahankan lumbung paceklik ini.

Lumbung Paceklik yang dimiliki oleh masyarakat Bonokeling Desa Pekuncen Kecamatan Jatilawang berjumlah 23 lumbung yang tersebar di 23 RT dalam lingkup 4 RW 
yaitu RW 01, RW 02, RW 03 dan RW 06. Terdapat perbedaan penyimpanan lumbung pada zaman dahulu dengan saat ini, dahulu lumbung diletakkan di rumah panggung yang terbuat dari kayu. Namun pada saat ini lumbung diletakkan di balai pertemuan RT. Mekanisme dalam lumbung paceklik berupa pengumpulan padi hasil panen sebesar yang telah disepakati masyarakat, yang kemudian diberlakukan sistem simpan pinjam padi. Selain itu, apabila padi yang tersimpan tidak digunakan akan dijual ke orang luar dengan hasil penjualan akan digunakan untuk pembangunan infrastruktur wilayah RT masing-masing, maupun pembelian inventaris yang bisa dipinjam oleh masyarakatnya sendiri. Namun saat ini, sudah banyak masyarakat yang mulai meninggalkan tradisi ini.

Fenomena ini merupakan wujud semangat kolektivitas petani yang terwujud dalam modal sosial yang dapat diamati melalui aktivitas tolong-menolong yang merupakan mekanisme sosial untuk menyelamatkan diri dan orang lain dari kondisi yang secara ekonomi rentan terhadap bahaya kekurangan pangan. Salah satu upaya dalam pelestarian terhadap budaya lokal berupa mempertahankan lumbung paceklik yang dimiliki oleh masyarakat Bonokeling di Desa Pekuncen Kecamatan Jatilawang dengan terus memperkuat modal sosial masyarakatnya.

Modal sosial merupakan aset lokal yang perlu dipelihara untuk tetap tumbuh dan berkembang di masyarakat, karena modal sosial dapat berfungsi sebagai pendorong pertumbuhan ekonomi yang merupakan komponen penting dalam pembangunan kesejahteraan sosial. Masyarakat diharapkan mampu menunjukkan modal sosial yang dimilikinya sebagai kekuatan di tengah kehidupan globalisasi yang terus menerus mengalami perubahan dari berbagai dimensi kehidupan. Menurut Putnam dalam Lawang (2005), modal sosial tidak akan habis jika dipergunakan, melainkan semakin meningkat.

Modal sosial menurut Putnam, menunjuk pada bagian-bagian dari organisasi sosial seperti kepercayaan, norma dan jaringan, yang dapat meningkatkan efisiensi masyarakat dengan memfasilitasi tindakan-tindakan yang terkoordinasi (Lawang, 2005). Menurut Putnam dan Fukuyama dalam Fahrudin (2012), modal sosial tidak hanya pada individu, tetapi pada kelompok, komunitas, bahkan di tingkat negara (state). Modal sosial menurut Cohen dan Prusak dalam Leksono (2009), modal sosial adalah kumpulan dari hubungan yang aktif diantara manusia: rasa percaya, saling pengertian dan kesamaan nilai dan perilaku yang mengikat anggota dalam sebuah jaringan kerja dan komunitas yang memungkinkan adanya kerjasama. Adapun konsep-konsep dasar modal sosial dalam Robert M.Z Lawang: 1. Kepercayaan (trust), dimana menurut Lawang (2005:45) menjelaskan inti kepercayaan antar manusia ada tiga hal yang 
saling terkait: Pertama, hubungan sosial antara dua orang atau lebih termasuk dalam hubungan ini adalah institusi dimana Lawang (2005:46) mengibaratkan Si A percaya pada institusi untuk kepentingannya, karena orang-orang dalam institusi itu bertindak. Kedua, harapan yang terkandung dalam hubungan itu yang kalau direalisasikan tidak akan merugikan salah satu atau kedua belah pihak. Ketiga, interaksi sosial yang memungkinkan hubungan dan harapan itu terwujud. Melalui ketiga dasar itu pula, kepercayaan dimaksudkan di sini menunjuk pada hubungan antara dua pihak atau lebih yang mengandung harapan yang menguntungkan salah satu atau kedua belah pihak melalui interaksi sosial. Menurut Robert D. Putnam dalam Hasballah (2006: 11) bahwa, Trust atau rasa percaya (mempercayai) adalah suatu bentuk keinginan untuk mengambil risiko dalam hubungan-hubungan sosialnya yang didasari oleh perasaan yakin bahwa yang lain akan melakukan sesuatu seperti yang diharapkan dan akan senantiasa bertindak dalam suatu pola tindakan yang saling mendukung.

2. Jaringan (network), dalam modal sosial dijelaskan oleh Robert M.Z Lawang (2005:61) sebagai berikut:

1) Ada ikatan antar simpul (orang atau kelompok) yang dihubungkan dengan media hubungan sosial. Kepercayaan itu dipertahankan oleh norma yang mengikat kedua belah pihak.
2) Ada kerja antar simpul (orang atau kelompok) yang melalui media hubungan sosial menjadi satu kerjasama, bukan kerja bersama-sama. Kepercayaan simbiotik bilateral dan kepercayaan interpersonal masuk dalam kategori ini.

3) Seperti halnya sebuah jaring (yang tidak putus) kerja yang terjalin antar simpul itu pasti kuat menahan beban bersama, dan malah dapat 'menangkap ikan' lebih banyak.

4) Dalam kerja jaring itu ada ikatan (simpul) yang tidak dapat berdiri sendiri. Semua simpul menjadi satu kesatuan ikatan yang kuat.

5) Media (benang atau kawat) dan simpul tidak dapat dipisahkan atau antara orang-orang dan hubungannya tidak dapat dipisahkan.

6) Ikatan atau pengikat (simpul) dalam kapital sosial adalah norma mengatur dan menjaga bagaimana ikatan dan medianya itu dipelihara dan dipertahankan.

3. Norma, tidak dapat dipisahkan dari jaringan dan kepercayaan. Robert M.Z Lawang (2005:70) mendefinisikan sifat norma sebagai berikut:

1) Norma itu muncul dari pertukaran yang saling menguntungkan (Blau, 1963; Fukuyama, 1999) dalam Lawang (2005:70). Artinya, kalau dalam pertukaran itu keuntungan hanya dinikmati oleh salah satu pihak saja, pertukaran sosial selanjutnya pasti akan terjadi, karena itu norma yang 
muncul di sini bukan sekali jadi melalui pertukaran saja. Dengan cara demikian hubungan pertukaran itu dipelihara.

2) Norma bersifat resiprokal, artinya isi norma menyangkut hak dan kewajiban kedua belah pihak yang dapat menjamin keuntungan yang diperoleh dari suatu kegiatan tertentu.

3) Jaringan yang terbina lama dan menjamin keuntungan kedua belah pihak secara merata, akan memunculkan norma keadilan yang melanggar prinsip keadilan akan dikenakan sanksi yang keras pula.

Lumbung paceklik termasuk salah satu perlindungan sosial yaitu skema mikro dan berbasis komunitas (micro and area based schemes to protect communities) salah satu elemen dari perlindungan sosial yang memberi perlindungan terhadap sekelompok orang. Tujuannya untuk merespon kerentanan dalam skala komunitas. Lumbung Paceklik sebagai program jaminan pangan yang dikembangkan untuk merespon kebutuhan pangan masyarakat Bonokeling.

Skema mikro dan berbasis komunitas (micro and area based schemes to protect communities) menurut Suharto (2015), salah satu elemen dari perlindungan sosial yang memberi perlindungan terhadap sekelompok orang. Tujuannya untuk merespon kerentanan dalam skala komunitas. Pada awalnya, program-program dikembangkan untuk memberikan perlindungan dan jaminan bagi petani di pedesaan dan pekerja sektor informal di perkotaan.

\section{METODE}

Penelitian ini dilaksanakan di masyarakat Bonokeling Desa Pekuncen Kecamatan Jatilawang Kabupaten Banyumas. Penelitian ini menggunakan pendekatan kualitatif dengan metode penelitian deskriptif. Penelitian kualitatif sebagai prosedur penelitian yang menghasilkan data deskriptif berupa kata-kata tertulis atau lisan dari orangorang dan perilaku yang dapat diamati. Peneliti memilih pendekatan kualitatif dikarenakan modal sosial berbeda dengan modal fisik dan modal manusia yang dapat diukur atau tangible dikarenakan memiliki wujud, akan tetapi modal sosial sulit dalam pengukurannya karena bersifat less tangible (tidak begitu kasat mata).

Menurut Usman (2018), modal sosial baru dapat diketahui keberadaannya atau dapat diidentifikasi gejalanya hanya apabila orang menjalin relasi-relasi sosial. Penelitian ini pun menggunakan metode penelitian di dalam pendekatan kualitatif yakni metode deskriptif. Metode deskriptif dimaksudkan untuk mempelajari masalah-masalah dalam masyarakat, serta tata cara yang berlaku dalam masyarakat serta situasi-situasi tertentu termasuk tentang hubungan serta proses-proses yang sedang berlangsung dan pengaruhpengaruh dari suatu fenomena, sehingga peneliti dapat mengetahui bagaimana modal sosial masyarakat Bonokeling dalam upaya 
melestarikan lumbung paceklik di Desa Pekuncen Kecamatan Jatilawang Kabupaten Banyumas.

Penentuan sumber data dalam penelitian ini menggunakan teknik non probability sampling melalui purposive sample atau teknik penentuan informan dengan beberapa pertimbangan dan tujuan melalui kriteria tertentu. Penentuan ini dilakukan dengan mempertimbangkan kepada sejauh mana informan terlibat dalam pelaksanaan lumbung paceklik ini serta kedudukan informan merupakan kedudukan yang berpengaruh dalam masyarakatnya. Cara pengumpulan data yang digunakan menggunakan wawancara mendalam, observasi dan studi dokumentasi.

Teknik analisis data tentang modal sosial masyarakat Bonokeling dalam pelestarian lumbung paceklik dilakukan secara terus menerus sejak awal dan proses penelitian berlangsung hingga akhir penelitian. Aktivitas analisis data mengikuti konsep Miles dan Huberman yaitu reduksi data, penyajian data serta penarikan kesimpulan.

\section{HASIL PENELITIAN}

\section{Karakteristik Informan Penelitian}

Informan dalam penelitian ini berjumlah enam orang yang terdiri dari empat orang masyarakat Bonokeling yang terlibat aktif dalam menjalankan lumbung paceklik dan diambil dari perwakilan masing-masing RW yang memiliki lumbung paceklik yaitu informan "KM", "SW", "K" dan "SK. Selain itu satu orang perwakilan aparat Desa Pekuncen yaitu informan "SN" serta satu orang yang lainnya merupakan Ketua Kelompok Masyarakat Adat Bonokeling yaitu informan "S".

Keenam informan ini dipandang mampu dalam mempresentasikan atau memberikan informasi terkait kondisi modal sosial yang dimiliki oleh masyarakat Bonokeling dalam melestarikan lumbung paceklik. Selain itu, keenam informan memiliki karakteristik yang dibedakan berdasarkan usia, pekerjaan dan jabatan informan di dalam kelompok masyarakat.

\section{Rasa saling percaya yang dibangun masyarakat Bonokeling dalam pelestarian lumbung paceklik}

Trust atau rasa percaya (proses mempercayai) sebagai salah satu aspek yang penting dalam modal sosial di masyarakat. Rasa saling percaya ini sebagai sikap saling memercayai dalam tetap melestarikan lumbung paceklik di kalangan masyarakat Bonokeling di Desa Pekuncen. Rasa saling percaya ini menyangkut rasa saling percaya kepada sesama masyarakat Bonokeling serta percaya kepada pihak luar (co-members). Pembahasan trust dalam konteks ini tidak hanya melibatkan aspek persepsi tetapi juga aspek partisipasi.

Pelaksanaan lumbung paceklik ini dilihat pada saat tahap peminjaman masyarakat meminjam tanpa adanya jaminan. Sikap 
kejujuran serta keterbukaan juga ditunjukkan oleh masyarakat, dalam hal ini adanya bukti buku catatan mengenai jumlah padi yang dipinjamkan dan dikembalikkan serta total bunga sesuai besaran peminjaman. Selain itu, tahapan yang ada dalam tradisi lumbung paceklik karena ada manfaat yang nyata dirasakan oleh masyarakat. Sehingga rasa saling percaya yang dibangun oleh sesama masyarakat Bonokeling erat dalam upaya tetap melestarikan lumbung paceklik di Desa Pekuncen.

Namun, keanggotaan yang dapat mengikuti tradisi ini tidak bersifat terikat sehingga adanya kebebasan masyarakat untuk keluar masuk dalam pengelolaan lumbung. Hal tersebut juga dipicu karena di Desa Pekuncen sudah tidak memberlakukan aturan bahwa anak harus selalu mengikuti ajaran kepercayaan orang tuanya. Hal tersebut dapat diperkirakan mulai terkikisnya lumbung paceklik. Namun para informan memiliki rasa optimis dan semangat bahwa lumbung paceklik ini akan terus bertahan tergantung dari kepengurusan wilayah RT yang akan tetap melestarikan tradisi ini.

Wujud adanya masyarakat Bonokeling saling percaya mengenai tradisi lumbung paceklik yaitu masyarakat masih berpartisipasi hingga sekarang mengikuti tradisi yang sudah turun temurun, serta pengelolaan yang dilakukan secara bersama-sama dan bertanggung jawab. Wujud kepercayaan seperti ini yang dapat memperkuat modal sosial masyarakat agar tradisi yang bertujuan untuk melindungi masyarakat dari kekurangan pangan dengan memiliki simpanan bahan pangan yang terjadi pada musim paceklik (musim kemarau berkepanjangan).

\section{Pola Jaringan yang Terjalin pada} Sesama Masyarakat Bonokeling dan Pihak Luar dalam Pelestarian Lumbung Paceklik

Jaringan merupakan hubunganhubungan sosial yang bermakna untuk tujuantujuan tertentu. Pelaksanaan tradisi lumbung paceklik akan lebih berkembang apabila melibatkan dengan beberapa pihak. Pola jaringan yang terjalin masih sederhana yaitu hanya antara sesama masyarakat Bonokeling dan penjual padi.

Pola jaringan yang dibentuk secara eksternal hanya dengan penjual padi, karena beberapa RT menjual padi hasil bunga untuk pemenuhan pembangunan dan kebutuhan lingkungan RT. Komunikasi yang terjadi berkaitan dengan harga padi pada tahun dimana masyarakat menjual dan adanya kesepakatan kedua belah pihak. Selain itu interaksi yang terjadi dengan penjual padi mendatangi pembeli untuk menimbang padi yang akan dijual.

Selain itu adanya dukungan dan partisipasi masyarakat Bonokeling dalam pelestarian lumbung paceklik bahwa dukungan dan partisipasi dengan masyarakat masih turut 
serta dan berperan aktif dalam pelaksanaan lumbung paceklik. Selain itu, masyarakat mengikuti musyawarah dalam menentukan kesepakatan bersama serta menaati hasil kesepakatan bersama. Hal tersebut merupakan dukungan dan partisipasi masyarakat dalam pelaksanaan lumbung paceklik di Desa Pekuncen, terutama oleh generasi tua.

Sedangkan dampak adanya kerjasama dengan pihak luar adalah adanya kemudahan ketika masyarakat akan menjual padi karena sudah saling mengenal dengan pihak tersebut. Hal ini berupa kemudahan koordinasi dalam kesepakatan harga jual padi. Sebagian besar masyarakat Bonokeling menjual padi kepada penjual dari luar Desa Pekuncen karena, adanya penarikan harga jual yang lebih tinggi. Selain itu, pemanfaatan lain dari hasil bunga peminjaman masyarakat yang telah dijual untuk keperluan lingkungan RT berupa pembangunan infrastruktur maupun kebutuhan lain. Sehingga pola jaringan yang terbentuk secara internal dan eksternal dapat mendorong pelestarian lumbung paceklik untuk tetap bertahan di tengah-tengah globalisasi di masyarakat.

\section{Norma-Norma yang Berlaku pada Masyarakat Bonokeling dalam Pelestarian Lumbung Paceklik}

Norma (norm) menjadi salah satu aspek yang penting dalam modal sosial, yang akan berperan dalam mengontrol perilaku di masyarakat. Norma merupakan sekumpulan aturan yang diharapkan untuk dipatuhi oleh anggota masyarakat di lingkungannya. Norma biasanya mengandung sanksi sosial yang dapat mengontrol perilaku individu dalam kehidupan bermasyarakat. Aturan kolektif yang ada di masyarakat biasanya tidak tertulis namun dapat dipahami oleh anggota masyarakat dan menentukan pola tingkah laku yang diharapkan dalam konteks hubungan sosial.

Pelaksanaan lumbung paceklik, aturan yang berlaku berdasarkan kesepakatan yang telah ditentukan oleh masing-masing RT. Selain itu juga, termasuk apabila ada masyarakat yang tidak dapat mengembalikkan pinjaman padi, terdapat peraturan lingkungan RT dengan pengembalian digantikan dengan senilai uang yang disesuaikan dengan harga padi pada bulan tersebut.

Setiap tahapan dan wilayah memiliki aturan yang berbeda, namun keduanya memiliki nilai masyarakat yang melekat karena sudah menjadi kebiasaan dalam internal masing-masing masyarakat. Nilai-nilai masyarakat yang ada berupa masyarakat melakukan kegiatan dengan kesepakatan dan musyawarah sehingga hasil yang ada dapat disepakati bersama.

Masyarakat memiliki nilai kejujuran yang tinggi, hal ini termasuk pada tahap peminjaman dan pengembalian yang bermodalkan rasa percaya terhadap sesama masyarakat. Selain itu, masyarakat memiliki kesadaran harus saling menolong 
masyarakatnya untuk memberikan perlindungan sosial dari kerentanan pangan. Selain itu, masyarakat memiliki toleransi yang tinggi, hal ini dibuktikan apabila ada masyarakat yang belum mampu membayar pinjaman, masyarakat memberikan keringanan untuk membayarkannya pada bulan yang akan datang hanya dengan syarat melapor pada pengurus RT.

\section{PEMBAHASAN}

\section{Karakteristik Informan}

Pemilihan informan didasarkan pada pendapat Moleong (2005:90) yang menyebutkan bahwa, informan adalah orang yang dimanfaatkan untuk memberikan informasi tentang situasi dan kondisi penelitian. Informan yang terpilih yang mampu dalam memberikan informasi mengenai situasi dan kondisi latar penelitian serta data yang diperlukan oleh peneliti di lapangan. Karakteristik informan yang diperlukan oleh peneliti digunakan untuk menentukan informan yang tepat guna memperoleh informasi dan data penelitian. Hal ini karakteristik yang digunakan oleh peneliti berupa nama informan, usia, jenis kelamin, pendidikan, pekerjaan, status perkawinan, alamat serta jabatan (kedudukan informan dalam masyarakat Bonokeling).

Setiap informan memiliki keunikannya masing-masing yang dipengaruhi oleh faktor dari internal maupun eksternal informan. Hal ini termasuk karakteristik berupa usia, jenis kelamin, pendidikan, pekerjaan, dan kedudukan informan di dalam masyarakat Bonokeling dapat mempengaruhi pola pikir dan pendapat informan mengenai aspek yang menjadi bahan penelitian yang dilakukan peneliti. Beberapa karakteristik tersebut akan berpengaruh pada data hasil pendapat yang disampaikan oleh informan, hal tersebut akan berbeda sesuai dengan kondisi masing-masing informan termasuk dalam bahasa yang disampaikan informan.

Pemilihan informan ini termasuk di dalamnya mempertimbangkan latar belakang informan sebagai penduduk asli Desa Pekuncen dan merupakan orang yang terlibat aktif dalam tradisi lumbung paceklik serta memahami kondisi keberadaan masyarakat Bonokeling di Desa Pekuncen. Selain itu, informan yang dipilih dalam penelitian ini diharapkan mampu merepresentasikan mengenai kondisi lumbung paceklik yang sudah menjadi tradisi lama, khususnya modal sosial masyarakat Bonokeling untuk tetap melestarikan keberadaan lumbung paceklik di Desa Pekuncen Kecamatan Jatilawang Kabupaten Banyumas.

Karakteristik informan berdasarkan kedudukannya di susunan masyarakat Bonokeling yaitu "KM", "SW", "K" dan "SK merupakan Ketua RT sebagai koordinator pelaksanaan lumbung paceklik di tingkat RT. Selain itu satu orang perwakilan aparat Desa Pekuncen yaitu informan "SN" serta satu orang 
yang lainnya merupakan Ketua Kelompok Masyarakat Adat Bonokeling yaitu informan "S". Karakteristik lain yaitu informan merupakan masyarakat asli Desa Pekuncen yang merupakan golongan tua yang masih melestarikan lumbung paceklik.

\section{Kepercayaan (Trust)}

Menurut Robert D. Putnam dalam Hasballah (2006: 11) bahwa Trust atau rasa percaya (mempercayai) adalah suatu bentuk keinginan untuk mengambil risiko dalam hubungan-hubungan sosialnya yang didasari oleh perasaan yakin bahwa yang lain akan melakukan sesuatu seperti yang diharapkan dan akan senantiasa bertindak dalam suatu pola tindakan yang saling mendukung.

Menurut pendapat di atas diartikan bahwa proses kepercayaan maupun rasa saling percaya, mempercayai merupakan bentuk masyarakat berani mengambil risiko dalam menjalani hubungan-hubungan sosial yang didasari oleh perasaan yakin terhadap masyarakat lain yang diharapkan adanya pola tindakan yang saling mendukung. Berdasarkan hasil penelitian bahwa masyarakat di Desa Pekuncen Kecamatan Jatilawang Kabupaten Banyumas memiliki rasa saling percaya yang tinggi, baik dengan sesama masyarakat Bonokeling maupun dengan pihak luar.

Berdasarkan teori menurut Putnam, bahwa masyarakat berani mengambil risiko dalam pelaksanaan lumbung paceklik ini dilihat pada saat tahap peminjaman masyarakat meminjam tanpa adanya jaminan. Sikap kejujuran serta keterbukaan juga ditunjukkan oleh masyarakat, dalam hal ini adanya bukti buku catatan mengenai berapa padi yang dipinjamkan dan dikembalikkan dan total bunga sesuai besaran peminjaman. Selain itu, tahapan yang ada dalam tradisi lumbung paceklik karena ada manfaat yang nyata dirasakan oleh masyarakat. Sehingga rasa saling percaya yang dibangun oleh sesama masyarakat Bonokeling erat dalam upaya tetap melestarikan lumbung paceklik di Desa Pekuncen.

\section{Gambar 1}

\section{Hasil Penelitian Kepercayaan Masyarakat}

Bonokeling dalam Pelestarian Lumbung

Paceklik di Desa Pekuncen Kecamatan

Jatilawang Kabupaten Banyumas

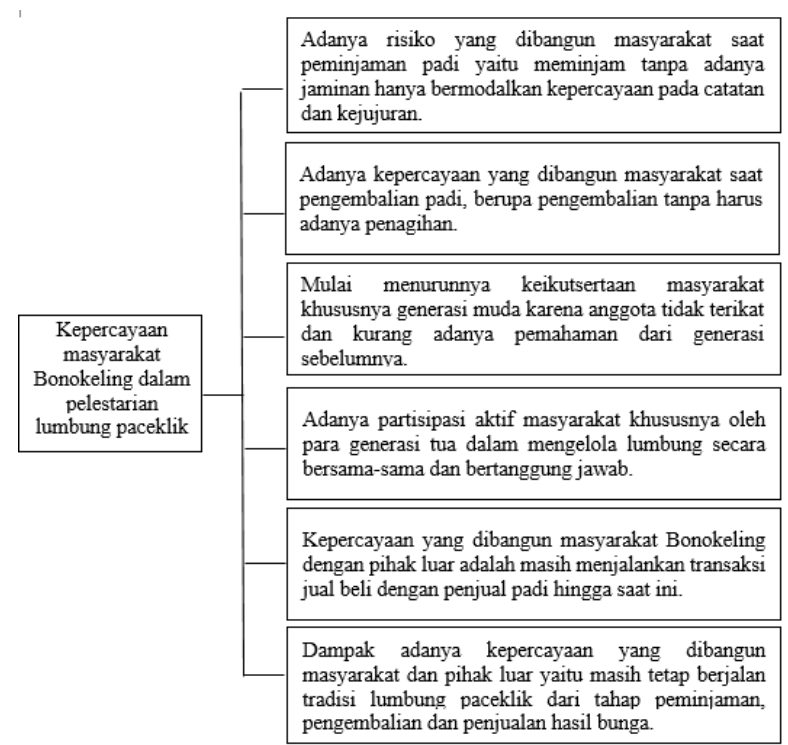

Konsep saling percaya menurut Anderson dalam Dinata (2014), bahwa hasil penelitian yang mendapatkan fakta bahwa 
generasi muda di Desa Pekuncen sudah mulai kurang mengenali tradisi lumbung paceklik yang sudah menjadi tradisi lama. Hal tersebut dikhawatirkan dapat menjadikan awal mulanya lumbung paceklik tidak dilestarikan kembali. Padahal, generasi muda harusnya mendapatkan turunan dari generasi sebelumnya yaitu orang tuanya. Hasil penelitian yang ada bertentangan dengan konsep saling percaya menurut Anderson dalam Dinata (2014), artinya tidak semua orang yang saling mengenal menghasilkan rasa saling percaya yang sama.

\section{Gambar 2}

\section{Hasil Penelitian Pola Jaringan Masyarakat}

Bonokeling dalam Pelestarian Lumbung

Paceklik di Desa Pekuncen Kecamatan

Jatilawang Kabupaten Banyumas

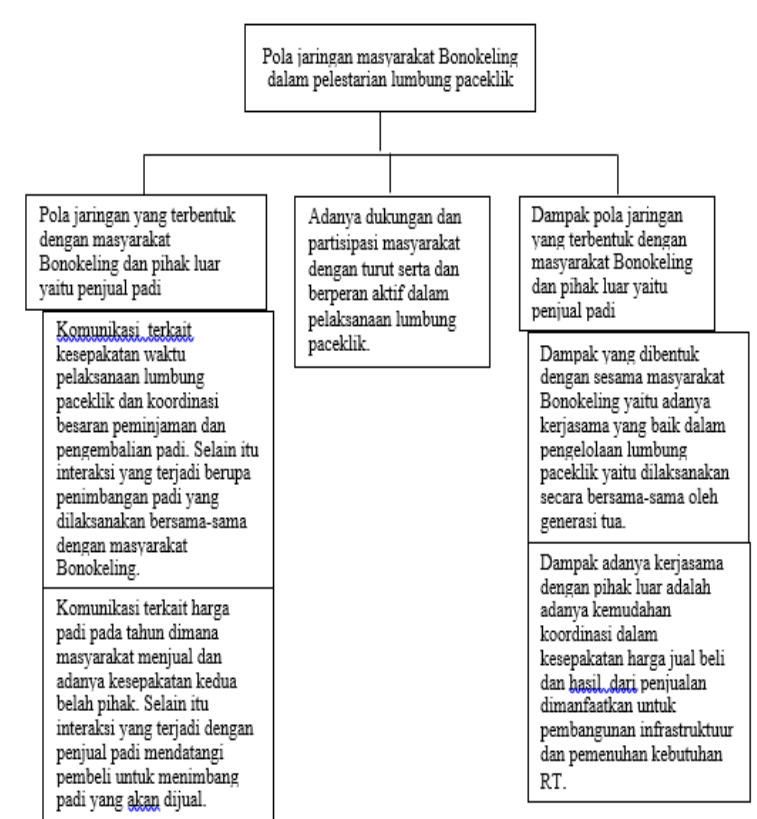

\section{Jaringan (Network)}

Konsep jaringan dalam modal sosial menurut Putnam dalam Lawang (2005), menjelaskan mengenai konsep tersebut sebagai berikut, "Jaringan memfasilitasi terjadinya komunikasi dan interaksi yang memungkinkan tumbuhnya kepercayaan dan memperkuat kerjasama". Hal ini diartikan bahwa jaringan memberikan fasilitas komunikasi dan interaksi dalam masyarakat yang dapat menumbuhkan rasa percaya dan memperkuat kerjasama yang ada.

Berdasarkan teori jaringan menurut Putnam dalam Lawang (2005), komunikasi dan interaksi yang terjadi antar masyarakat Bonokeling pada saat tradisi tersebut yang umumnya dilaksanakan dua kali dalam satu tahun pada Bulan Ranteban (musim penghujan) dan Bulan Sadon (musim kemarau). Komunikasi yang terjadi berupa melakukan kesepakatan terkait waktu pelaksanaan dan koordinasi besaran peminjaman dan pengembalian padi. Selain itu interaksi yang terjadi berupa penimbangan padi yang dilaksanakan bersama-sama.

Menurut Hasballah (2006: 6), Modal sosial akan kuat tergantung pada kapasitas yang ada dalam kelompok masyarakat membangun sebuah asosiasi berikut membangun jaringannya. Hal ini diartikan sebagai adanya kemampuan sekelompok orang dalam melibatkan diri dalam suatu jaringan hubungan sosial. Berdasarkan hasil penelitian, maka relevan dampak adanya pola jaringan yang dibentuk dengan sesama masyarakat Bonokeling yaitu adanya kerjasama yang baik 
dalam pengelolaan lumbung paceklik yaitu dilaksanakan secara bersama-sama.

\section{Norma (Norm)}

Menurut Putnam dalam Lawang (2005), norma bersifat resiprokal, artinya norma menyangkut hak dan kewajiban kedua belah pihak yang dapat menjamin keuntungan yang diperoleh dari suatu kegiatan tertentu. Norma merupakan sekumpulan aturan yang diharapkan dipatuhi oleh sejumlah anggota masyarakat.

Aturan-aturan yang ada biasanya tidak tertulis namun dapat dipahami oleh anggota masyarakatnya dan dapat menentukan pola tingkah laku yang diharapkan dalam konteks hubungan sosial. Menurut Hasballah (2006: 13), konsep utama modal sosial adalah norma sosial yang ada pada masyarakat atau kelompok. Hal tersebut dapat mengotrol adanya bentuk-bentuk perilaku yang dimunculkan oleh anggota masyarakat.

Berdasarkan hasil penelitian mengenai masyarakat Bonokeling dalam pelestarian lumbung paceklik di Desa Pekuncen Kecamatan Jatilawang Kabupaten Banyumas bahwa, aturan yang berlaku berdasarkan kesepakatan yang telah ditentukan oleh masing-masing RT. Selain itu juga, termasuk apabila ada masyarakat yang tidak dapat mengembalikkan padi dengan padi, terdapat peraturan lingkungan RT yang dapat mengembalikkannya dengan senilai uang yang disesuaikan dengan harga padi pada bulan tersebut.

Setiap tahapan dan wilayah memiliki aturan yang berbeda, namun keduanya memiliki nilai masyarakat yang melekat karena sudah menjadi kebiasaan dalam internal masing-masing masyarakat. Nilai-nilai masyarakat yang ada berupa masyarakat melakukan kegiatan dengan kesepakatan dan musyawarah sehingga hasil yang ada dapat disepakati bersama.

\section{Gambar 3}

\section{Hasil Penelitian Norma Masyarakat}

Bonokeling dalam Pelestarian Lumbung

Paceklik di Desa Pekuncen Kecamatan Jatilawang Kabupaten Banyumas

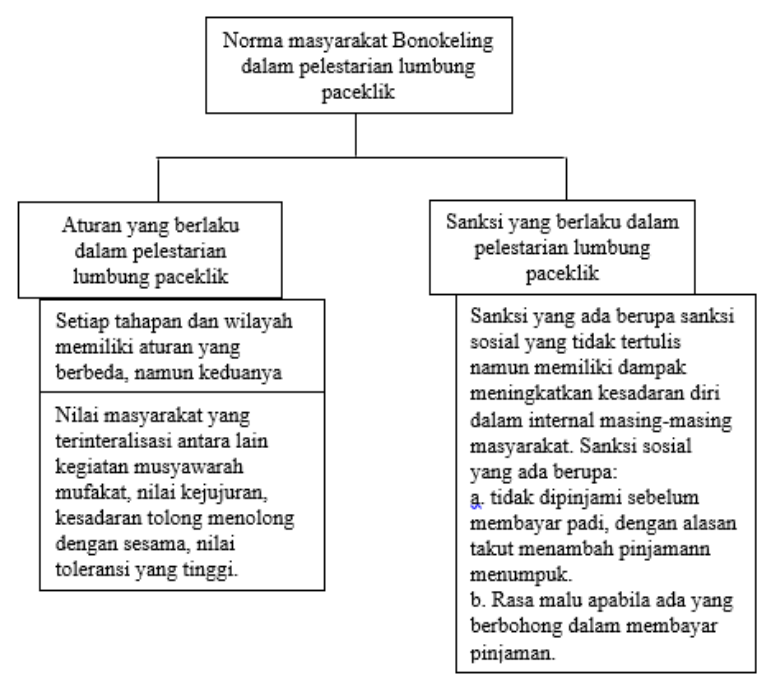

Menurut Putnam dalam Lawang (2005), orang yang melanggar norma resiprokal yang berdampak pada berkurangnya keuntungan dikedua belah pihak, akan diberi sanksi negatif yang sangat keras. Hal yang ditemukan di lapangan bahwa, adanya sanksi 
sosial yang diterapkan oleh masyarakat Bonokeling dalam melestarikan lumbung paceklik di Desa Pekuncen.

Hal ini termasuk apabila ada masyarakat yang mengembalikan padi tidak sesuai waktunya, namun adanya pembatasan dari masyarakat karena menganggap keberatan dalam pengembalian berikutnya. Selain itu, sanksi sosial yang diterapkan masyarakat juga apabila ada masyarakat yang tidak jujur mengenai jumlah peminjaman dan pengembalian, tidak adanya sanksi khusus. Hal ini namun lebih ditekankan pada rasa malu yang akan diterima oleh masyarakat tersebut apabila terbukti salah. Oleh karena itu, sanksisanksi yang ada menekankan pada dampaknya dapat meningkatkan kesadaran diri dalam internal masing-masing masyarakat.

Norma merupakan salah satu hal yang sangat penting dalam modal sosial, hasil penelitian yang dilakukan juga generasi muda kurang memperhatikan norma yang ada dalam pelaksanaan lumbung paceklik, sehingga hal ini berpengaruh pada kepercayaan dan jaringan yang dibangun dengan sesama masyarakat Bonokeling. Generasi muda kurang memahami aturan yang ada dalam pelaksanaan lumbung paceklik, sehingga mereka kurang memiliki rasa memiliki dalam menjaga tradisi lumbung paceklik serta hubungan dengan sesama masyarakatnya khususnya dalam hal saling tolong menolong kebutuhan pangan kurang erat. Hal tersebut karena mereka merasa tidak menjadi bagian dalam tradisi lumbung paceklik, sehingga dikhawatirkan sebagai awal runtuhnya modal sosial di masyarakat Bonokeling.

\section{KESIMPULAN}

Hasil penelitian menggambarkan bahwa modal sosial masyarakat Bonokeling dalam upaya melestarikan lumbung paceklik di Desa Pekuncen Kecamatan Jatilawang cukup baik, namun terdapat beberapa aspek modal sosial yang perlu untuk dioptimalkan. Deskripsi dari penelitian yaitu berupa aspek modal sosial kepercayaan (trust) dari ketiga aspek yang ada, bahwa kepercayaan yang dibangun oleh sesama masyarakat Bonokeling sudah cukup baik. Hal ini sesuai dengan penemuan di lapangan bahwa adanya risiko yang dibangun masyarakat saat tahap peminjaman padi tanpa jaminan dan pengembalian padi tanpa adanya penagihan, hal tersebut hanya bermodalkan pada penanaman sikap kejujuran sehingga menciptakan hubungan yang erat antar sesama masyarakat. Namun dalam aspek ini, perlu adanya hal yang dioptimalkan yaitu karena, terdapat penurunan tingkat partisipasi masyarakat untuk mengikuti tradisi ini khususnya generasi muda yang sudah mulai kurang memahami tradisi ini.

Aspek jaringan (network) dalam modal sosial masyarakat Bonokeling dalam upaya melestarikan lumbung paceklik, memiliki jaringan yang cukup baik. Jaringan yang 
dibangun yaitu antara sesama masyarakat Bonokeling terutama yang hingga saat ini masih melestarikan lumbung paceklik di masing-masing RT khususnya generasi tuanya. Selain dengan sesama masyarakat Bonokeling, jaringan yang dibangun juga dengan pihak luar yaitu penjual padi.

Modal sosial dengan aspek norma (norm) pada masyarakat Bonokeling dalam pelestarian lumbung paceklik sudah baik. Norma yang bersifat resiprokal telah ada di Desa Pekuncen. Setiap lumbung paceklik di lingkungan RT telah memiliki aturan-aturan tertentu yang harus disepakati oleh masyarakatnya sendiri. Aturan-aturan yang ada tidak tertulis, namun sudah melekat dalam diri masyarakat karena sudah menjadi kebiasaan yang baik. Nilai-nilai masyarakat yang ada antara lain kegiatan musyawarah mufakat, nilai kejujuran, kesadaran tolong menolong dengan sesama, nilai toleransi yang tinggi.

Selain itu, aturan yang ada selalu diikuti oleh sanksi. Hasil penelitian ini menyebutkan bahwa sanksi yang berlaku di masyarakat Bonokeling tidak bersifat tertulis namun berupa sanksi sosial yang terinternalisasi di masyarakat.

Norma merupakan salah satu hal yang sangat penting dalam modal sosial, hasil penelitian yang dilakukan juga generasi muda kurang memperhatikan norma yang ada dalam pelaksanaan lumbung paceklik, sehingga hal ini berpengaruh pada kepercayaan dan jaringan yang dibangun dengan sesama masyarakat Bonokeling.

Hasil penelitian menunjukkan bahwa modal sosial pada masyarakat Bonokeling dalam pelestarian lumbung paceklik telah mengalami penurunan kualitas apabila dibandingkan dengan kondisi modal sosial masyarakat Bonokeling Desa Pekuncen secara umum pada waktu dahulu. Perubahan kondisi ini ditandai dengan fakta dominan yang meliputi krisis kepercayaan atau menurunnya kepercayaan di dalam mengikuti dan berpartisipasi dalam tradisi lumbung paceklik. Hal ini dipengaruhi oleh beberapa hal yaitu tidak terikatnya anggota, serta kurangnya pemahaman generasi muda terhadap tradisi ini karena generasi tua kurang menurunkan ajaran generasinya ke anak putu Bonokeling.

\section{DAFTAR PUSTAKA}

Adi, Isbandi Rukminto. 2008. Intervensi Komunitas : Pengembangan Masyarakat Sebagai Upaya Pemberdayaan Masyarakat. Jakarta : PT Rajagrafindo Persada

\section{Kesejahteraan}

Sosial: (Pekerjaan Sosial, Pembangunan

Sosial, dan Kajian Pembangunan). Jakarta: PT RajaGrafindo Persada Damanik, Juda. 2008. Pekerjaan Sosial Jilid 2. Jakarta: Direktorat Pembinaan Sekolah Menengah Kejuruan

Dinata, Rendiansyah Putra. 2014. Modal Sosial Masyarakat Sekitar Kawasan Industri di 
Desa Sukaresmi Kecamatan Cikarang

Selatan Kabupaten Bekasi. Bandung: STKS

Dwiningrum, Siti Irine Astuti. 2014. Modal

Sosial dalam Pengembangan Pendidikan

(Perspektif Teori dan Praktik).

Yogyakarta: UNY Press

Fahrudin, Adi. 2012. Pemberdayaan

Partisipasi dan Penguatan Kapasitas

Masyarakat. Bandung : Humaniora

2012. Pengantar

Kesejahteraan Sosial. Bandung: Refika Aditama

Field, John. 2010. Modal Sosial. Yogyakarta:

Kreasi Wacana

Guzman, Leonora S De. 1983. Fundamentals of

Social Work. Manila, Philipines: School

Association of Social Work

Hasballah, Jousairi. 2006. Social Capital:

Menuju Keunggulan Budaya Manusia

Indonesia. Jakarta: MR-United Press

Ife, Jim dan Frank Tesoriero. 2006. Alternatif

Pengembangan Masyarakat di Era

Globalisasi : Community Development.

Yogyakarta : Pustaka Pelajar

Lawang, Robert M.Z. 2005. Kapital Sosial :

dalam Perspektif Sosiologik. Depok:

Fisip UI Press

Listyawati, Andayani. (2017, Maret). Budaya

Lokal sebagai Upaya Memperkuat Nilai

Kesetiakawanan Sosial Masyarakat.

Jurnal Penelitian Kesejahteraan Sosial,

16.(1),33-42.
Moleong, Lexy J. 2005. Metodologi Penelitian Kualitatif. Bandung : PT Remaja Rosdakarya

Nawawi, dkk. (2016, Juni). Resistensi Komunitas Bonokeling Terhadap Islam Puritan. Jurnal Kebudayaan Islam, 14, (1), 90-113.

Pincus, Allen dan Anne Minahan. 1973. Social Work Practice: Model and Method. Itasca, Illinois: F.E Peacock Publishers, Inc.

Purwana, Bambang H. Suta, dkk. 2015. Sistem Religi Komunitas Adat Bonokeling di Desa Pekuncen, Kecamatan Jatilawang, Kabupaten Banyumas. Yogyakarta : Balai Pelestarian Nilai Budaya (BPNB)

S, Leksono. 2009. Runtuhnya Modal Sosial, Pasar Tradisional : Perspektif Emic Kualitatif. Malang : CV Citra

Setiadi, Elly M dan Usman Kolip. 2010. Pengantar Sosiologi: Pemahaman Fakta dan Gejala Permasalahan Sosial: Teori, Aplikasi dan Pemecahannya. Jakarta: Kencana

Siporin, Max. 1975. Introduction to Social Work Practice. New York: Macmillan Publishing Co., Inc.

Suharto, Edi. 2013. Kemiskinan dan Perlindungan Sosial di Indonesia : Menggagas Model Jaminan Sosial Universal Bidang Kesehatan. Bandung : Alfabeta 
Sukoco, Dwi Heru. 1989. Pekerjaan Sosial

Sebagai Profesi, Metoda, dan proses Pertolongan. Bandung : Sekolah Tinggi Kesejahteraan Sosial

Usman, Sunyoto. 2018. Modal Sosial. Yogyakarta: Pustaka Pelajar

Zastrow, Charles. 2014. Introduction to Social Work and Social Welfare: Empowering People (Eleventh Edition). Belmont, CA: Brooks Cole, Cengage Learning.

Zubaedi. 2013. Pengembangan Masyarakat: Wacana dan Praktik. Jakarta: PT Fajar Interpratama Mandiri 